\title{
TERMITE ASSEMBLAGES AND DECOMPOSITION OF TISSUE PAPER BAITS ALONG A GRADIENT OF LAND USE INTENSIFICATION IN OWENA, SOUTHWEST NIGERIA
}

\author{
OLUGBEMI, B.O.* \\ Raw Materials Research and Development Council, P.M.B. 656, Akure, Ondo State, Nigeria \\ (phone: +234-7032270187) \\ *Corresponding author \\ e-mail: drolugbemi@yahoo.com \\ (Received $27^{\text {th }}$ July 2011; accepted $29^{\text {th }}$ January 2013)
}

\begin{abstract}
Land-use intensification has a direct effect on termite encounters, individuals and species richness in an ecosystem. Species richness decreases with increase in land-use intensity. The functional groups are also affected by the degree of disturbances within the land systems, with a higher percentage of damp-wood termites occurring in the primary forest, while the fungus growers are more predominant in the disturbed environment. However, termite densities are independent of land-use systems. Termite activities and decomposition of tissue paper baits increases with Increase in land-use intensity, and are independent of seasonal changes. Land-use intensification could therefore be an important factor in determining species richness, functional composition and abundance of termites in a disturbed or undisturbed ecosystem.
\end{abstract}

Keywords: species richness, land-use systems, termite encounters, party sizes, density

\section{Introduction}

Termites are known to play key roles in decomposition processes, nutrient cycling, nitrogen fixation, carbon fluxes, soil creation, distribution and inversion (Collins, 1983; Jones, 1990; Bond, 1993; Lawton et. al., 1996; Bignell et. al., 1997). These functions, according to Davies et. al. (1999), are largely dependent on the species decomposition of termite assemblage.

Termite activities exert positive effects on soil processes and properties (Holt and Lapage, 2000). In the soils of tropical forests, termites constitute about $95 \%$ of insect biomass, and could reach a value of up to $100 \mathrm{gm}^{-3}$ (Watt et. al., 1997). Bignell and Eggleton (2000) also recorded fungus growing termites in this region having the ability to consume almost all dead woods and over $50 \%$ of leaf and grass litters.

Termite assemblages differ in forests at different succession stages after logging (Eggleton et.al., 1995, 1996, 1997), and they change further following conversion of land for agriculture (Lee and Wood, 1971).

The loss of forest biodiversity due to conversion of land for use in agriculture, construction, recreation and other artificial purposes are always accompanied by selective loss of some termite functional groups, especially the soil feeders (De Souza and Brown, 1994; Eggleton et. al., 1997, 1998, 2002). However, there was increase in the relative abundance of fungus growing termites with land-use intensification (Eggleton et. al., 1997, 2002).

Termites exhibit a wide range of dietary, foraging and nesting habits, with many species showing high degree of resource specialization (Wood, 1977). Their influence therefore on decomposition processes is dictated to a large extent by the species and functional composition of the local termite assemblage (Davies, 2002; Schuurman, 
2005). Thus the wood feeders, fungus growers or soil feeders, play different roles in the decomposition processes (Tayasu et.al., 1997), and are considered as major ecosystem engineers (Bignell and Eggleton, 2000).

In view of the roles termites play in soil processes, especially in tropical ecosystems (Wardle, 2002), there is a need to study the effects of land-use intensification vis-à-vis termite-mediated ecological processes, such as decomposition and consumption of cellulotic materials (Okwakol and Sekamatte, 2007). In the past, assessment of ecological functions of wood feeding and fungus growing termites have been done using cellulose baits (Lafage et. al., 1973; Nash et. al., 1999), yielding abundance data that was consistent with results from other studies.

This study is therefore aimed at determining the relationship between termite richness along a gradient of land-use intensificstion, as well as quantifies termitemediated decomposition processes using tissue paper baits consumption pattern in the rain forest region of Owena, Southwest Nigeria.

This study will therefore evaluate the following:

a. Could land-use intensification bring about a change in termite density in a given studied area?

b. Could there be a change in termite species richness and functional composition along a gradient of land-use intensity?

c. Would increasing land-use intensity affect termite-mediated processes and decomposition of tissue bait along the gradient?

\section{Data analysis}

Mean values for all data were calculated and subjected to appropriate statistical analysis. Values obtained for plant characteristics along the gradient of land use were presented graphical and attached with error bars.

Data for termite encounters, party sizes and density were tested for significance using the chi square test $\left(\chi^{2}\right)$. The hypothesis is: Ho: $\chi^{2}=0$; HA: $\chi^{2} \neq 0$. Therefore, where the calculated $\chi_{\mathrm{c}}^{2}>$ tabulated $\chi_{\mathrm{t}}^{2}$, then significant level is assumed. However if $\chi_{\mathrm{c}}{ }^{2}<\chi_{\mathrm{t}}^{2}$, then these values are not significantly different along the gradient.

Mean values for occurrence of termite functional groups were subjected to the oneway ANOVA test to determine the effect of land-use on these termite's groups. The decision rule is: If the calculated $F_{c}$ ratio $>$ the table $F_{t}$, then land-use has significant effect on the occurrence of termite's functional groups. However, if $F_{c}<F_{t}$, then the effect of land-use on termite functional groups is not significant.

Mean consumption and decomposition of tissue paper baits along the gradient of land-use were analyzed with the two-way ANOVA test in view of the multiplicity of mean data, and the need to control the effect of the sources of variations. The decision rule is: If $F_{c}>F_{t}$, significant consumption along the gradient is assumed. If $F_{c}<F_{t}$, consumption of tissue paper bait is not significant along the gradient of land-use.

The test for difference of means was adopted, using the student t- distribution with $(\mathrm{n}-1)$ degrees of freedom, to determine the effect of seasonal changes on consumption of tissue paper baits by termites along the gradient of land-use. 


\section{Materials and methods}

\section{Study area}

This study was carried out in the rainforest belt of Owena, Southwest Nigeria. This area lies in the central part of Ondo State $\left(6^{\circ} 5^{\prime \prime} \mathrm{N}, 5^{\circ} 30^{\prime \prime}-5^{\circ} 31^{\prime \prime} \mathrm{E}\right)$, and adjacent to the sub-station of the Cocoa Research Institute of Nigeria (CRIN). This area lies at an elevation of $300 \mathrm{~m}$ above sea level. It receives an annual rainfall of $1500-2000 \mathrm{~mm}$, with distinct wet and dry seasons. The humidity range of this area is $75 \mathrm{mmHg} \pm 5 \mathrm{mmHg}$, while temperature values ranged between $21{ }^{\circ} \mathrm{C}$ and $29{ }^{\circ} \mathrm{C}$ throughout the year.

The soils in this area is deeply loamy, well drained and with $\mathrm{pH}$ in the range of 7.508.50. This area therefore supports a variety of plants and animal species suitable for the subsistence of agricultural practices of the people. The predominant crops grown in this area includes Cocoa, Cassava, Yam, Cocoyam, Maize, Cowpea, Plantain, Banana, Kola, Vegetables and Fruits.

Studies were carried out in four land-use systems in this area. These are: Primary forest (forests with lowest disturbance, and with trees older than 70 years): Disturbed forest (forest with some degrees of disturbance, such as logging, hunting, and grazing): Secondary forest (middle-aged forest with trees aged 20-30 years, which had been left to regenerate after years of logging and human disturbances: Farmlands (cultivated land with diverse crops grown for subsistence farming) (Table 1).

Table 1. Description of Land-use system in Owena area, Southwest Nigeria

\begin{tabular}{c|l|l}
\hline S/N & Land-use System & \multicolumn{1}{c}{ Description } \\
\hline 1. & $\begin{array}{l}\text { Near Primary } \\
\text { Forest }\end{array}$ & Forests of lowest disturbance, dense canopy with trees older than 50 years \\
2. & Disturbed Forest & $\begin{array}{l}\text { Primary Forest with some degree of human disturbance, such as logging, } \\
\text { grazing, and with lighter canopy compared to primary forest } \\
\text { Mid-aged forest of 20-30 years. Mostly of regenerated trees. } \\
\text { Cultivated land of diverse characteristics, comprising few trees, plots of } \\
\text { cultivated land for subsistence agriculture, and high percentage of bare } \\
\text { ground. }\end{array}$ \\
\hline
\end{tabular}

\section{Measurements of trees and vegetation parameters}

The following parameters were measured: tree canopy height (m), canopy cover $(\%)$, bush cover $(\%)$, and litter depth $(\mathrm{cm})$ along the gradient to determine their influence on termite assemblage and activities.

\section{Estimation of density and functional composition of termite assemblages}

Following the methods and protocols of Jones and Eggleton (2000), transects $(100 \mathrm{~m} \times 2 \mathrm{~m})$ were established in each of the four land-use system to estimate the density and functional composition of termite assemblages between January 2010 and January 2011. For standardization of the sampling methods (Jones et. al., 2003), each transect was divided into 20 continuous plots of $5 \mathrm{~m} \times 2 \mathrm{~m}$, and each plot sampled for one man-hour by searching for termites within the plots as well as within soil samples taken from an area of $12 \mathrm{~cm} \times 12 \mathrm{~cm}$ down to a depth of $10 \mathrm{~cm}$. 


\section{Determination of sampling encountered}

According to Jones (2000), the number of encounters across a whole transect is a surrogate for termite density. In a similar vein, Gathorne-Hardy et. al. (2001), reported a correlation of 0.9 between encounters and species richness in termites, indicating similarity in pattern between species richness and encounters.

Termite samples encountered were determined up to species level, and categorized into five groups: a-humus feeders, b-fungus growers, c-other wood feeders, d-dampwood termites, and e-dry-wood termites. Donovan et. al., 2001 and Davies (2002) classified these termites into three broad groups, namely wood/litter feeders, soil feeders, and fungus growers. Termite population densities were estimated from individuals encountered in foraging parties during this study.

\section{Determination of termite activity through decomposition experiment}

Decomposition experiments were carried out through the establishment of bait stations in each of the four studied areas. It consists of unscented and unbleached tissue paper rolls of $10 \mathrm{~cm} \times 12 \mathrm{~cm} \times 250 \mathrm{~cm}$ of 250 sheets. 16 of these were mounted on a $3 \mathrm{~m}$ $\times 3 \mathrm{~m}$ grid in each of the four studied area, at $1 \mathrm{~m}$ interval from one another. To prevent unraveling (LaFarge et. al., 1973), the baits were reinforced with a strip of packing tape, and installed in an upright position. Polythene planter bags were placed over the baits to prevent them from the effect of heavy rains, while holding them in position with the aid of a u-shaped steel pins, one half of which was inserted centrally through the planter bags (Dawes-Gromadzki and Spain, 2003). All litters and debris were removed to ensure that the uncovered bases of the baits were in contact with the soil surface.

The baits are inspected regularly once a week for 25 weeks after installation, for termite presence and activities. This is done by lifting up the baits and recording termite presence, damage and/or gallery materials. Termite damage through tissue paper removal was usually estimated through the quantity of tissues consumed during inspection. The experiment was replicated 5 times in each of the land-use system from January to July 2010 (corresponding to dry-rainy season), and repeated from July 2010 to January 2011 (corresponding to rainy-dry season).

\section{Results}

Measurements of vegetation characteristics showed a gradual decrease in, tree height, canopy cover, litter depth, shrubs and occurrence of dead wood matter (Fig. 1), from primary forest through disturbed forest, secondary forest to farmland, respectively.

Termite encounters in all the transects showed a consistent pattern in density as well as in species richness from the sampled areas. These encounters decrease with land-use intensification. In the primary forest, with significant tree height, canopy cover, and higher accumulation of dead wood on the forest floor, the number of termite encounters averaged 38 per transect, while encounters in the disturbed and secondary forests were 28 and 22 per transect respectively (Fig. 2). On the farmland, 15 termite encounters were recorded. Analysis of these encounters showed that land-use intensification significantly affects termite encounters along the gradient of land-use $\left(\chi_{c}^{2}>\chi_{t}^{2}{ }_{0.05}\right.$, 3 df.). However, the party size which is the number of individuals recorded for each encounters increases with land-use intensity, an indication of the significant effect of land-use on termite activity $\left(\chi_{\mathrm{c}}^{2}>\chi_{\mathrm{t} 0.05}^{2}, 3 \mathrm{df}\right.$. Fig. 2). 

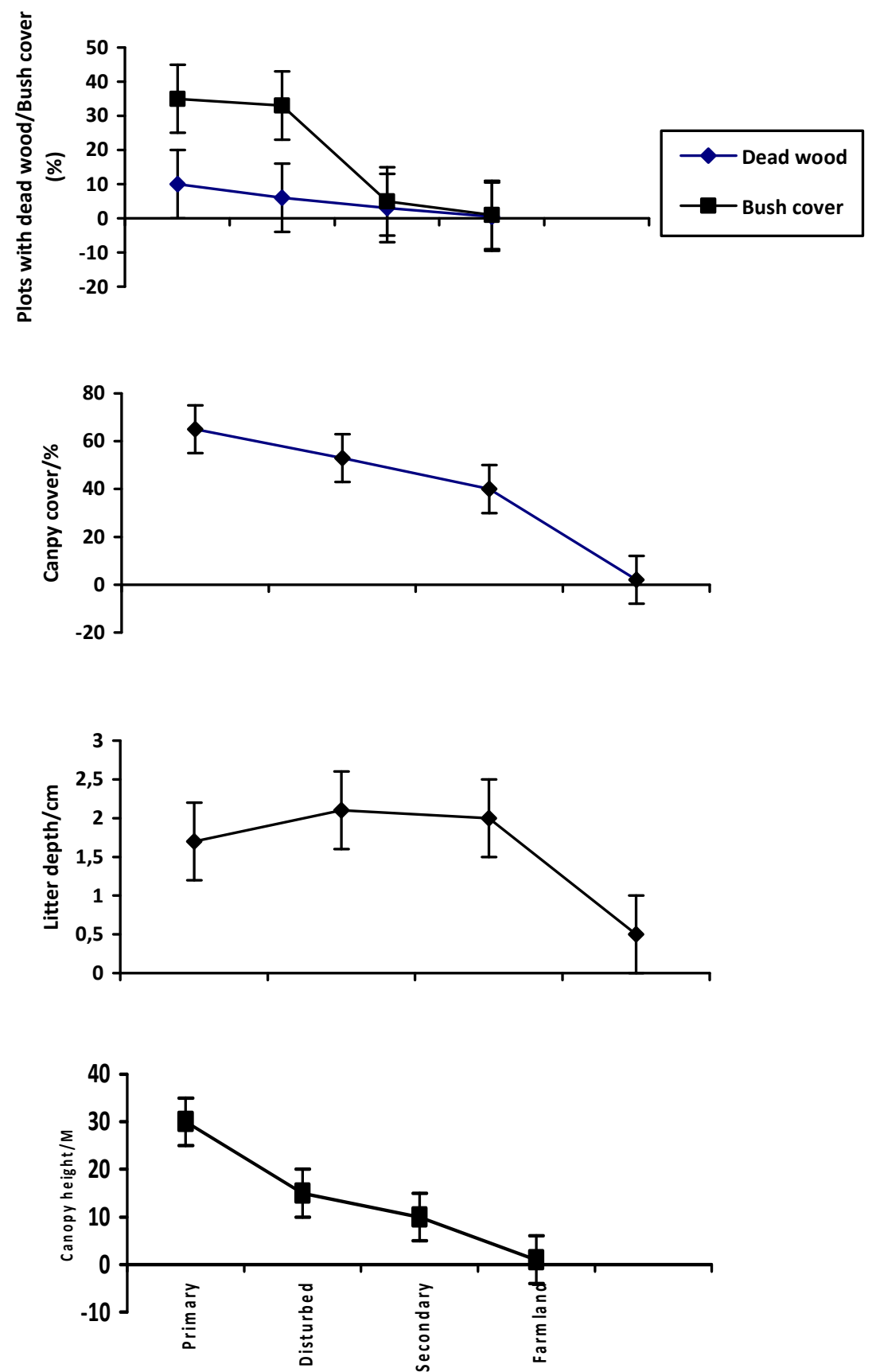

Figure 1. Plant characteristic along a gradient of land-use disturbances in Owena, Southwest Nigeria

Analyses of these encounters also showed a gradual and systematic decrease in generic and species richness along the gradient of land-use intensification. 30 species belonging to 19 genera were recorded in the primary forest, while the disturbed forest recorded a total of 23 termite species belonging to 15 genera. In the secondary forest, 20 species representing 14 genera were found, while a further reduction to 14 species belonging to 10 genera were recorded on the farmland (Table 2; Fig. 2). 
Table 2. Termite species found in the four land-use system in Owena area of Southwest Nigeria. Category codes: $D W=$ dry-wood termites; $D P W=$ damp-wood termites; $F G=$ fungus growers; $H F=$ humus feeders; $O W F=$ other wood feeders

\begin{tabular}{|c|c|c|c|c|c|}
\hline $\begin{array}{c}\text { Termite species encountered/ } \\
\text { Feeding group }\end{array}$ & Family & $\begin{array}{c}\text { Primary } \\
\text { Forest }\end{array}$ & $\begin{array}{c}\text { Disturbed } \\
\text { Forest }\end{array}$ & $\begin{array}{c}\text { Secondary } \\
\text { Forest }\end{array}$ & Farmland \\
\hline Cryptotermes brevis & Kalotermitidae & + & + & & \\
\hline C. havilandi & & + & + & & \\
\hline Neotermes aburiensis & & + & + & + & + \\
\hline N. nigeriensis & & + & + & & \\
\hline Coptotermes intermedius DPW & Rhinotermitidae & + & + & + & + \\
\hline C. sjostedt $\quad D P W$ & & + & + & & \\
\hline $\begin{array}{r}\text { Schedorhinotermes lamanianus } \\
D P W\end{array}$ & & + & + & + & + \\
\hline Acanthotermes acanthothorax & Termitidae & + & + & + & \\
\hline Ancistrotermes crucifer & & + & + & + & + \\
\hline A. carnithorax & & + & + & + & \\
\hline A. guineensis & & & + & + & \\
\hline Macrotermes bellicosus & & + & + & + & + \\
\hline M. subhyalinus & & + & + & + & + \\
\hline Microtermes spp. & & & & + & + \\
\hline Odontotermes magdalenae $F G$ & & & & + & + \\
\hline O. pauperans $\quad F G$ & & & + & + & + \\
\hline $\begin{array}{l}\text { Pseudacanthotermes militari } \\
\text { FG }\end{array}$ & & + & + & + & \\
\hline P. minimus $\quad F G$ & & + & + & + & \\
\hline \multirow{2}{*}{$\begin{array}{l}\text { Allognathotermes aburiensis } \\
H F\end{array}$} & & + & & & \\
\hline & & & & & \\
\hline Astalotermes quietus & & + & & & \\
\hline Amitermes evuncifer & & + & + & + & + \\
\hline Apilitermes longiceps & & + & & & \\
\hline Basideatitermes aurivil & & + & & & \\
\hline B. potents & & + & & & \\
\hline Cubitermes ocultus & & & + & + & \\
\hline $\begin{array}{l}\text { Microcerotermes fuscotibialis } \\
\text { OWF }\end{array}$ & & + & + & + & \\
\hline Probositermes unboliferus & & + & & & \\
\hline$O W F$ & & & & & \\
\hline P. aburiensis & & + & & & \\
\hline Termes bacilli & & + & & & \\
\hline Nasutitermes arborum & & + & + & + & + \\
\hline Nasutitermes lujae & & + & + & & + \\
\hline N. fuller & & + & & & \\
\hline Trinervitermes geminates $O W F$ & & + & + & + & + \\
\hline T. occidentalis & & + & & & \\
\hline T. trinervius & & + & + & + & + \\
\hline
\end{tabular}

The density of termites encountered in this study was obtained from the product of mean encounters and party sizes for each of the land-use system (Fig. 3). Results showed a gradual increase in termite density along the gradient, but these increases were not significant enough as to confer any influence by a change in land-use $\left(\chi_{\mathrm{c}}^{2}<\chi_{\mathrm{t}}^{2}\right.$ 0.05 , 3df.) (Fig. 3). 

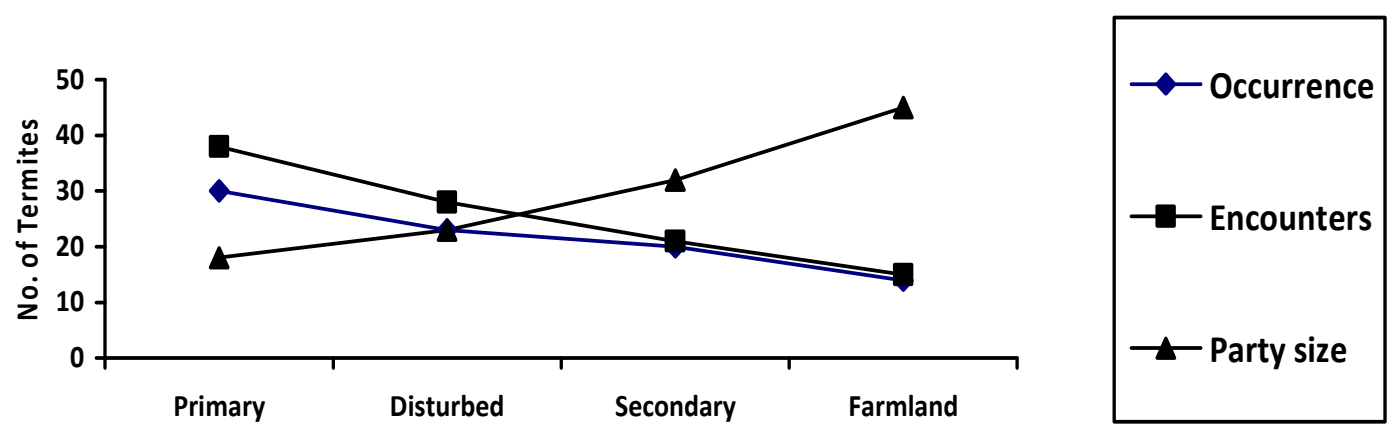

Figure 2. Mean values of termite encounters along the gradient of land-use system in Owena area, Western Nigeria

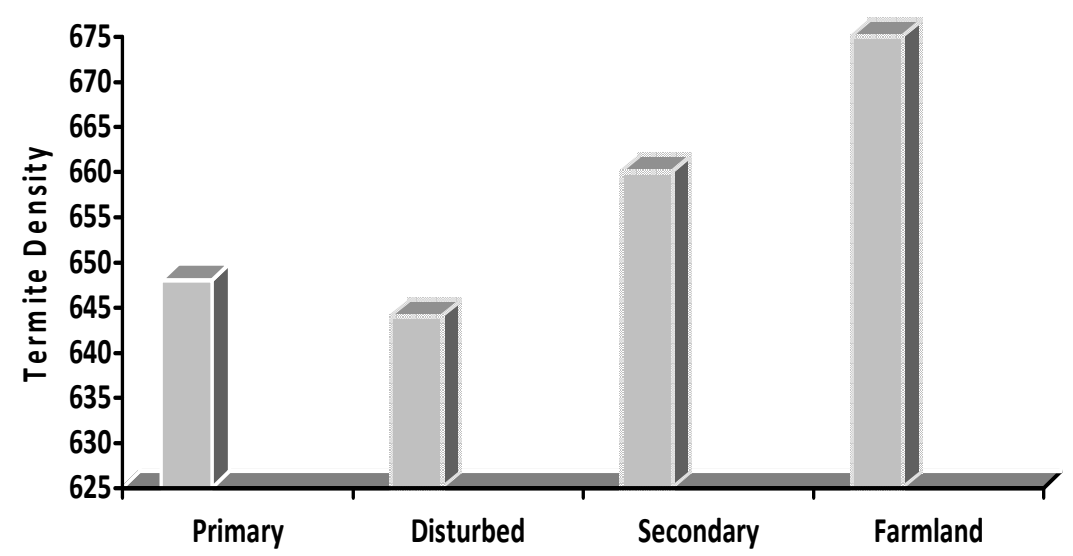

Figure 3. Termite densities along the gradient of land-usse in Owena area of Western Nigeria

The functional composition of the termite assemblages followed a decrease from the primary forest to the cultivated farmland. These functional groups are classified into five categories: a-humus feeders; b- fungus growers; c- other wood feeders (including vegetable harvesters); d- damp-wood termites; e- dry-wood termites. A higher percentage of damp-wood termites $(45 \%)$ were encountered in the primary forest, compared with $30 \%$ of fungus growers (Fig. 4). In the disturbed and secondary forests, as well as on the farmland, fungus growers forms a higher percentage of termites encountered (54\%, 60\%, and 68\% respectively) (Fig. 4).

Analysis of these results showed that land-use system significantly affects termite's functional group composition along the gradient of land-use intensification (ANOVA $F_{c}=15.94$; critical value of $F_{0.05,4,15}=5.86$; Since $F_{c}>F$, then significant effect of landuse on functional group composition is assumed, Table 3). 
Table 3. Statistical analysis of the effect of land-use intensificstion on the occurrence of termite's functional groups in the different land-use system in Owena area of Southwest Nigeria, using one-way ANOVA test

\begin{tabular}{c|c|c|c|c}
\hline Source of variation & SS & DF & Mean SS & F $_{\mathbf{c}}$ Ratio \\
\hline Among the transects & 5823.5 & 4 & 1941.17 & 15.94 \\
Within the transects & 1948.5 & 15 & 121.78 & \\
Total & 7772 & 19 & & \\
\hline
\end{tabular}

Critical value of $\mathrm{F}_{.05,4,15} \approx 5.86 ; \mathrm{F}_{\mathrm{c}}=15.94 ;$ Since $\mathrm{F}_{\mathrm{c}}>\mathrm{F}_{0.05,4,15}$, then it follows that land-use intensity have significant effect in the occurrence of termite functional groups along the gradient of land-use in owena area of Southwest Nigeria.

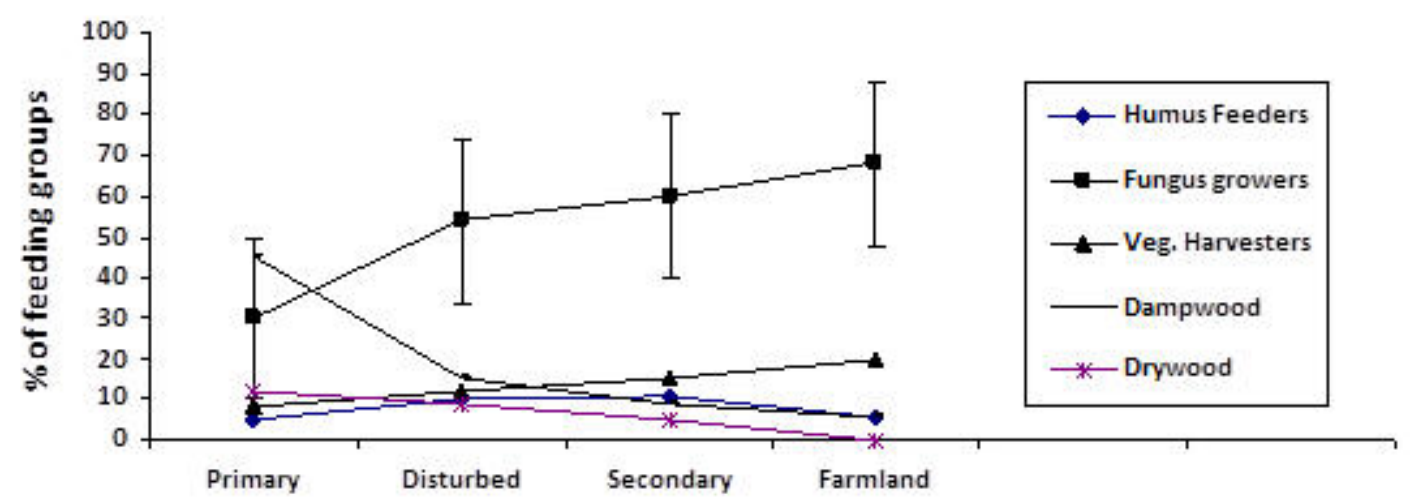

Figure 4. Mean percentage of functional groups encountered along the gradient of land-use in Owena, Western Nigeria

Although species building high mounds, such as Macrotermes bellicosus were encountered, especially within the farmland outside of the transect, their presence had been captured in the transects.

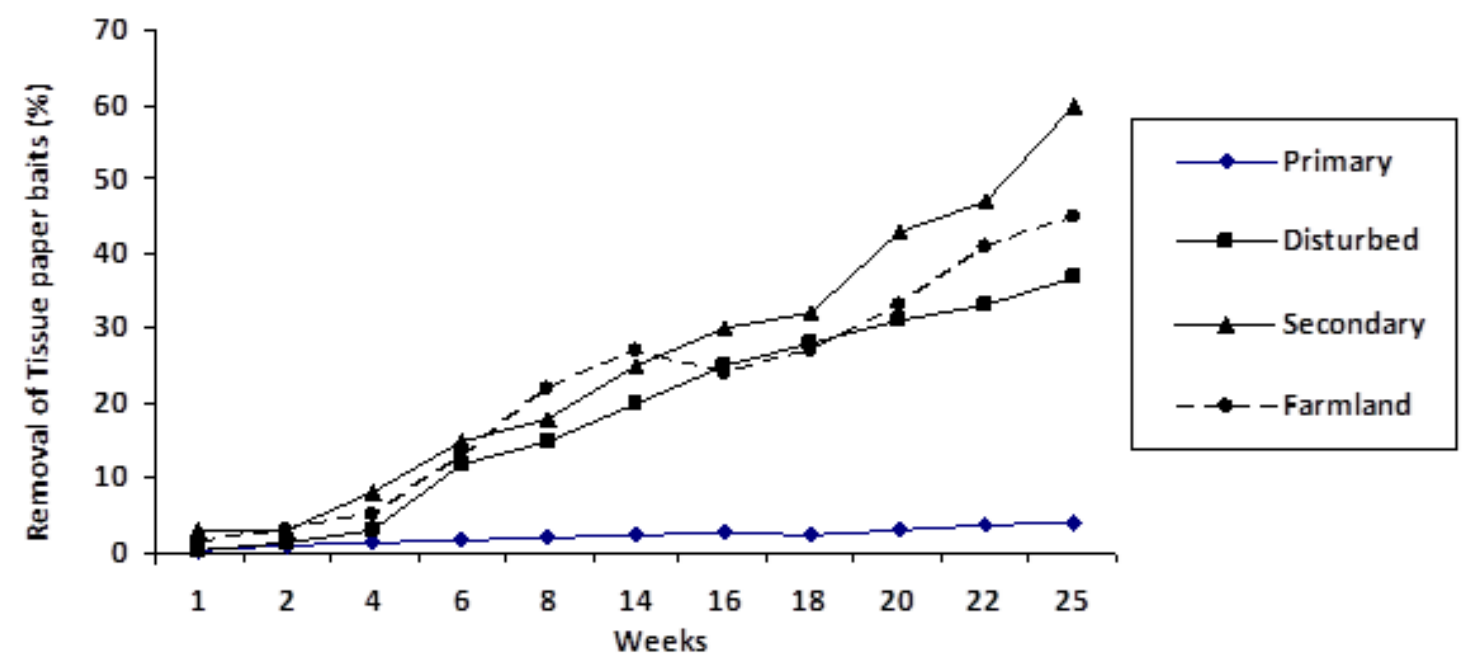

Figure 5. Mean removal of tissue paper baits along the gradient of land-use intensity in Owena area of Western Nigeria (Jan. 2010 - July 2010) 
In the decomposition experiments, conducted during the dry-rainy season (Jan. 2010July 2010), consumption of the tissue paper baits showed a distinct pattern along the gradient of land-use (Fig. 5). In the primary forest, consumption of the baits was in the range of $0.3 \%$ to $4.1 \%$, while in the disturbed forest, the range was within $0.5 \%$ to $37 \%$. Removal of tissue baits also followed a gradual increase from $3 \%$ to $60 \%$ in the secondary forest, while a consumption rate of $1.5 \%$ to $45 \%$ was recorded on the farmland over the same period (Fig. 5). These results showed a significant effect of land-use system on tissue paper consumption by termites, which also translate to increase in termite activities along the gradient of land-use (ANOVA : $\mathrm{F}_{\mathrm{c}}=8.37 ; \mathrm{F}_{0.05}$, $10,30=2.70$. Since $F>F_{0.05,10,30}$, then significant consumption of tissue paper baits is assumed, Table 4).

Table 4. Statistical analysis of tissue paper removal by termites along the gradient of landuse intensification in Owena area of Southwest Nigeria, using two-way ANOVA test (Jan. 2010-July 2010)

\begin{tabular}{c|c|c|c|c}
\hline Source of variation & SS & DF & Mean SS & F $_{\mathbf{c}}$ Ratio \\
\hline Among the groups & 5512.11 & 10 & 551.21 & 8.37 \\
Blocks & 3550.36 & 3 & 1183.45 & 17.98 \\
Within the groups & 1975.02 & 30 & 65.83 & \\
\hline
\end{tabular}

Critical value of $F_{0.05,10,30}=2.70 ; F_{c}=8.37$; Since $F_{c}>F_{0.05}, 10,30$, land-use intensity along the gradient significantly affects the consumption of tissue paper baits within this dry-rainy periods.

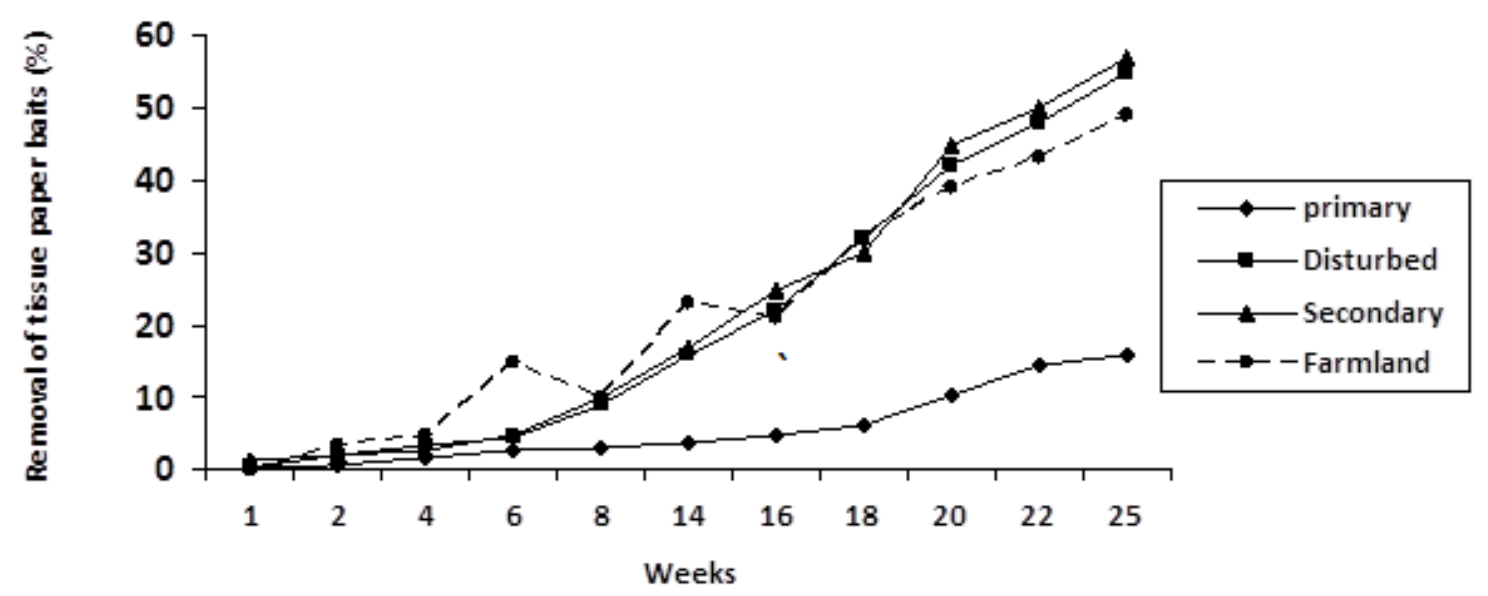

Figure 6. Mean removal of tissue paper baits along the gradient of land-use intensity in Owena area of Western Nigeria (July 2010 - Jan. 2011)

In the second half of this experiment, corresponding to the rainy-dry season in this area (July 2010-January 2011), the rate of bait consumption followed a similar pattern to that of the first half year, irrespective of the seasonal change (ANOVA; $F_{c}=14.34$; $F_{0.05,10,30}=2.70$. Since $F>F_{0.05}, 10,30$, then there was significant consumption of tissue paper baits along the gradient of land-use, Table 5). Bait consumption was lowest in the 
primary forest, followed by an Increasing consumption pattern in the disturbed and secondary forests respectively, and dropping slightly on the farmland (Fig. 6).

Table 5. Statistical analysis of tissue paper baits by termites along the gradient of land-use intensification in Owena area of Southwest Nigeria, using a two-way ANOVA test (July 2010-Jan. 2011)

\begin{tabular}{c|c|c|c|c}
\hline Source of variation & SS & DF & Mean SS & $\mathbf{F}_{\mathbf{c}}$ Ratio \\
\hline Among the groups & 9774.89 & 10 & 977.49 & 14.34 \\
Blocks & 1838.49 & 3 & 612.83 & 8.99 \\
Within the groups & 2044.62 & 30 & 68.15 & \\
\hline
\end{tabular}

Critical value of $F_{0.05}, 10,30=2.70 ; F_{c}=14.34 ;$ Since $F_{c}>F_{0.05}, 10,30$, then land intensity along the gradient significantly affects the consumption of tissue paper baits within the rainy-dry periods.

In comparing and testing the differences between the means obtained in Tables 4 and 5 , results showed that seasonal changes (rainy and dry seasons) does not have any significant influence on the consumption pattern of tissue paper baits by termites in this area, irrespective of the season $\left(\mathrm{t}_{0.01}, 3 \mathrm{df}=4.541: \mathrm{t}_{\mathrm{c}}=-0.136\right.$; Since $\mathrm{t}_{\mathrm{c}}<\mathrm{t}_{0.01}$ at $3 \mathrm{df}$, then there was no significant difference in the consumption pattern).

\section{Discussion}

Termite assemblage and species richness along a gradient of land-use intensification in the area under study showed a distinct pattern of taxonomic and functional composition of termites along these differing forest disturbances.

In the primary forest, where tree height and canopy cover are in excess of $35 \mathrm{~m}$ and $15 \mathrm{~m}$ respectively, termites belonging to 19 genera, 30 species and 5 functional groups were recorded. This diversity in species and functional composition could be attributed to the moist and buffered microhabitats provided by the trees and bush cover in the primary forest (Dibog et., 1999), thereby facilitating the survival of these soft bodied insects (De Souza and Brown, 1994; Jones et., 2003).

A reduction in termite genera and species composition were found in the disturbed forest, with 15 genera and 23 species, while in the secondary forest, a total of 20 termite species belonging to 14 genera were encountered. 14 termite species belonging to 10 genera were found on the farmland. This loss in generic and species richness is correlated along the gradient of forest disturbances and farming activities.

The functional composition of termites also showed different variations. There was increase in relative abundance of fungus growers, while a significant reduction was observed for soil and other wood/litter feeders. Increase in intensification could determine the presence of defined functional groups of termites at any given site, which could point to the level of disturbance of such ecosystem.

Mean termite encounters along the gradient were not significantly different from one another. Encounters across all transect averaged $2.65 \mathrm{~m}^{-2}$ (range of 1.5 to $3.8 \mathrm{~m}^{-2}$ ). Each of these encounters and their party sizes are calculated as a representative estimate of termite colony density in the studied area. Atignon et. al. (2005), reported $0.5-1.1 \mathrm{~m}^{-2}$ encounters in a semi deciduous forests and plantations in Benin, West Africa. 
As with other studies, termite density was independent of land-use intensity in tropical ecosystems (Eggleton et. al., 1995; Genet et. al., 2001). In the near primary forest, mean termite density was $684 \mathrm{~m}^{-2}$ individuals, while in the disturbed forest, it was $644 \mathrm{~m}^{-2}$. In the secondary forest, mean termite density was calculated to be $660 \mathrm{~m}^{-2}$, while on the farmland it was $675 \mathrm{~m}^{-2}$. These densities appear to be on the low side considering termite densities reported in other studies. Eggleton (1995), reported densities of 2282-6967 $\mathrm{m}^{-2}$ in near primary forest, 2328-6703 $\mathrm{m}^{-2}$ in old secondary forest, and 5170 individuals per square meter in plantations of Terminalia ivoriensis in Cameroun.This could be attributed to multiple interactive factors operating in this area. As observed in this study, land-use intensity has an insignificant effect on termite density along the gradient of land-use. Eggleton et. al. (1995), and Davies et. al., (1999), made similar observations.

The rate of decomposition and removal of parts of tissue papers was closely correlated with the activities of termites in this area. This pattern of cellulose removal is highest in the secondary and disturbed forests as well as on the farmland. This pattern is closely associated with significant increase in the activity of fungus growers, the Macrotermitinae, in these three land systems. A low rate was however recorded in the primary forest, a situation that may be attributable to the stable environment which presents a diversity of interactive components within that system.

Termite activities and consumption of cellulose may therefore be dependent on the degree of land-use intensification and disturbances within a given ecosystem.

\section{Conclusion}

Termites play an important role in the decomposition and removal of cellulose materials in tropical ecosystems. Termite species richness and assemblage are sensitive to changes in land-use, with resultant effect on their taxonomic and functional composition.

This study therefore revealed a decrease in species richness from primary forest to the farmland, while encounters and party sizes increased along with land-use intensification. However, termite densities are independent of land-use systems.

Activities of termites through tissue bait removal increased with increasing level of disturbance, with the lowest rate being recorded in the primary forest.

Land-use intensification could therefore be an important factor in determining species richness, functional composition and abundance of termites in a disturbed or undisturbed ecosystem. The degree of disturbance may also affect the activities of termites within such an environment.

\section{REFERENCES}

[1] Atignon, S.E., Lachat, T., Sinsin, B., Nagel, P., Pevelin, R. (2005): Termite assemblages in a West African semi-deciduos forest and teak population. - Agriculture, Ecosystems and Environment 110: 318-326.

[2] Bignell, D.E., Eggleton, P. (2000): Termites in ecosystems. - In: Abe, T., Bignell, D.E., Higashi, M. (eds.) Termites, Evolution, Sociality, Symbioses, Ecology. Kluwer Academic Press, Dordrecht, The Netherlands.

[3] Bignell, D.E., Eggleton, P., Nunes, L., Thomas, K.L. (1997): Termites as mediators of carbon fluxes in tropical forest: budgets for carbon dioxide and methane emissions. - In: 
Watt, A.D., Stork, N.E., Hunter, M.D. (eds.) Forests and Insects. Chapman and Hall, London, U.K.

[4] Bond, W.J. (1993): Keystone species. Biodiversity and Ecosystem Functions (Eds. Schultze, E.D., Mooney, H.A.). Ecological Studies 99. - Springer-Verlag, Berlin, Germany.

[5] Collins, N.M. (1983): Termite populations and their role in litter removal in Malaysian rain forests. - In: Sutton, S.L., Whitmore, T.C., Chadwick, C.A. (eds.). Tropical Rain Forest: Ecology and Management. Blackwell Scientific Publications, Oxford, U.K.

[6] Davies, R.G. (2002): Feeding group responses of a Neotropical termite assemblage to rain forest fragmentation. - Oecologia 133: 233-242.

[7] Davies, R.G., Eggleton, P., Dibog, L., Lawton, J.H., Bignell, D.E., Brauman, A., Hartman, C., Nunes, L., Holt, J., Rouland, C. (1999): Successional response of a forest termite assemblage to experimental habitat perturbation. - Journal of Applied Ecology 36. 946-962.

[8] Dawes-Gromadzki, T.Z., Spain, A.V. (2003): Seasonal patterns in the activity and species richness of surface-foraging termites (Isoptera) at paper baits in a tropical Australian Savanna. - Journal of Tropical Ecology 19: 449-456.

[9] De Souza, O.F.F., Brown, V.K. (1994): Effects of habitat fragmentation on Amazonian termite communities. - Journal of Tropical Ecology 10: 197-206.

[10] Dibog, L., Eggleton, P., Norgrove, L., Bignell, D.E., Hauser, S. (1999): Impacts of canopy cover on soil termite assemblages in an agrisilvicultural system in Southern Cameroon. - Bulletin of Entomological Research 89: 125-132.

[11] Donovan, S.E., Eggleton, P., Dubbin, W.E., Batchelder, M., Dibog, L. (2001): The effect of a soil-feeding termite, Cubitermes fungifaber (Isoptera: Termitidae) on soil properties: termites may be an important source of soil microhabitat heterogeneity in tropical forests. - Pedobiologia 45: 1-11.

[12] Eggleton, P., Bignell, D.E., Hauser, S., Dibog, L., Norgrove, L., Madong, B. (2002): Termite diversity across an anthropogenic gradient in the humid forest zone of West Africa. - Agriculture, Ecosystems ad Environment 90: 189-202.

[13] Eggleton, P., Bignell, D.E., Sands, W.A., Mawdsley, N.A., Lawton, J.H., Wood, T.G., Bignell, N.C. (1996): The diversity, abundance and biomass of termites under differing levels of disturbance in the Mbalmayo Forest Reserve, Southern Cameroon. Philosophical Transactions of the Royal Society, Series B 351: 51-68.

[14] Eggleton, P., Bignell, D.E., Sands, W.A., Waite, B., Wood, T.G., Lawton, J.H. (1995): The species richness of termites (Isoptera) under differing levels of forest disturbance in the Mbalmayo Forest Reserve, Southern Cameroon. - Journal of Tropical Ecology 11: $85-98$.

[15] Eggleton, P., Davies, R.G., Bignell, D.E. (1998): Body size and energy use in termites (Isoptera): the response of soil feeders and wood feeders differ in a tropical forest assemblage. - Oikos 81: 525-530.

[16] Gathorne-Hardy, F., Syaukani, Eggleton, P. (2001): The effects of altitude and rainfall on the composition of the termites (Isoptera) of the Leuser Ecosystem (Sumatra, Indonesia). - Journal of Tropical Ecology 17: 379-393.

[17] Genet, J.A., Genet, K.S., Burton, T.M., Murphy, P.G. and Lugo, A.E. (2001): Response of termite community and wood decomposition rates to habitat fragmentation in a subtropical dry forest. - Tropical Ecology 42: 35-49.

[18] Holt, J.A., Lepage, M. (2000): Termites and Soil properties. - In: Abe, T., Bignell, D.E. and Higashi, M. (eds.) Termites, Evolution, Sociality, Symbioses, Ecology. Kluwer Academic Press, Dordrecht, The Netherlands.

[19] Jones, D.T. (2000): Termite assemblages in two distinct montane forest types at $1000 \mathrm{~m}$ elevation in Maliau Basin, Sabah. - Journal of Tropical Ecology 16. 271-286.

[20] Jones, D.T., Eggleton, P. (2000): Sampling termite assemblages in tropical forests: testing a rapid biodiversity assessment protocol. - Journal of Applied Ecology. 37: 191-203. 
[21] Jones, D.T., Susilo, F.X., Bignell, D.E., Hardiwinoto, S., Gillison, A.N., Eggleton, P. (2003): Termite assemblage collapse along a land-use intensification gradient in lowland central Sumatra, Indonesia. - Journal of Applied Ecology 40: 380-391.

[22] Jones, J.A. (1990): Termites, Soil fertility and Carbon cycling in dry tropical Africa: a hypothesis. - Journal of Tropical Ecology. 6: 291-305.

[23] Larfage, J.P., Nutting, W.L., Haverty, M.I. (1973): Desert subterranean termites: a method for studying foraging behavior. - Environmental Entomology 2: 954-956.

[24] Lawton, J.H., Bignell, D.E., Bloemers, G.F., Eggleton, P., Hodda, M.E (1996): Carbon flux and diversity of nematodes and termites in Cameroon forest soils. - Bioderversity and Conservation 5: 261-273.

[25] Lee, K.E., Wood, T.G. (1971): Termites and Soils. - Academic Press, London, U.K.

[26] Nash, M.S., Anderson, J.P., Whitford, W.G. (1999): Spatial and temporal variability in relative abundance and foraging behavior of subterranean termites in desertified and relatively intact Chihuahuan Desert ecosystems. - Applied Soil Ecology 12: 149-157.

[27] Okwakol, M.J.N., Sekamatte, M.B. (2007): Soil macrofauna research in ecosystems in Uganda. - African Journal of Ecology 45: 2-8.

[28] Schuurman, G. (2005): Decomposition rates and termite assemblage composition in semi arid Africa. - Ecology 86: 1236-1249.

[29] Tayasu, I., Abe, T., Eggleton, P., Bignell, D.E. (1997): Nitrogen and Carbon isotope ratios in termites: an indicator of trophic habitat along the gradient from wood-feeding to soil feeding. - Ecological Entomology 22: 343-351.

[30] Wardle, D.A. (2002): Communities and ecosystems. Linking the aboveground and belowground components. - Princeton University Press, Princeton and Oxford.

[31] Watt, A.D., Stork, N.E., Eggleton, P., Srivastava, D., Bolton, B., Larsen, T.B., Brendell, M.J.D., Bignell, D.E. (1997): Impact of forest loss and regeneration on insect abundance and biodiversity. - In: Watt, A.D., Hunter, M.D. (eds.). Forests and Insects.Chapman and Hall, London, U.K.

[32] Wood, T.G. (1977): Food and feeding habits of termites. - In: Brian, M.V. (ed.). Production Ecology of Ants and Termites) International Biological Programme, Cambridge University Press, Cambridge. 